\title{
Inventory of the Recommendations for Patients with Pollen Allergies and Evaluation of Their Scientific Relevance
}

\author{
Solenne Roubelat ${ }^{\mathrm{a}} \quad$ Jean-Pierre Besancenot ${ }^{\mathrm{b}} \quad$ Daniel Bley ${ }^{\mathrm{c}} \quad$ Michel Thibaudon $^{\mathrm{b}}$ \\ Denis Charpin ${ }^{a}$ \\ ${ }^{a}$ Aix-Marseille University and the French Clean Air Association, Marseille, France; ${ }^{b}$ French National Aerobiological \\ Network, Brussieu, France; CUMR 7300 ESPACE, Arbois Mediterranean Europole, Aix-en-Provence, France
}

\section{Keywords}

Allergy · Avoidance · Evaluation · Guidelines · Hay fever ·

Pollen $\cdot$ Prevention $\cdot$ Recommendations

\begin{abstract}
Pollens are responsible for allergic rhinitis, conjunctivitis, and asthma. The incidence of these diseases, which have adversely impacted the social and professional lives of people who are allergic to pollen, has tripled in the past 25 years. Official institutes, health care institutions, public interest groups, and mainstream news media provide people who are allergic to pollen with advice aimed at reducing their symptoms. The aim of this work was to provide an inventory of the prevention guidelines in the world and to evaluate their scientific relevance. A PubMed search was carried out using specific keywords. The scientific relevance of the recommendations was evaluated based on the publications disproving or confirming their merit. The guidelines issued by 12 countries in Europe, North America, and Australia were inventoried. The recommendations for avoidance were most often based on scientific data regarding their impact on pollen exposures, but they have not been clinically validated. Several studies provided additional details, however, that allowed the guidelines to be further substantiated. These
\end{abstract}

karger@karger.com

(c) 2020 S. Karger AG, Basel

www.karger.com/iaa

Karger guidelines have been adopted in numerous industrialized countries in the world, and they generally appear to be of relevance.

(c) 2020 S. Karger AG, Basel

\section{Introduction}

The first step in tackling a pollen allergy is finding ways to avoid the allergen. However, pollination is a natural phenomenon, occurring in step with the seasons. People who are allergic can, therefore, not fully avoid contact with pollen-derived allergens. In light of this, official institutes, health care institutions, public interest groups, and the mainstream media provide prevention guidelines for people who are allergic to pollen, with the aim of promoting behaviors that allow exposure to pollen to be reduced and to attenuate the allergic symptoms. Although these empirical recommendations are generally based on common sense, their efficacy nonetheless warrants being properly documented.

The objectives of this general review were, on the one hand, to generate a comprehensive list of the guidelines

Edited by: O. Palomares, Madrid. 
for avoidance and, on the other hand, to evaluate the scientific relevance of these recommendations and to assess the differences and similarities of the guidelines found in the various sources that provide this type of information. The first part of this work consisted of creating an inventory of the official guidelines of various industrialized countries. We performed an Internet search based on keywords and the websites of official institutes, health institutions, and citizen groups using Google as a search engine.

For the second part of this work, we used PubMed as a search engine. We searched using specific keywords, retaining the articles in English or French. All study sites, all publication dates, and all types of study were accepted. Publications unrelated to the topic of interest were excluded.

\section{Inventory of the Guidelines for Pollen Avoidance}

We compiled the guidelines devised by 12 countries across Europe, North America, and Australia. The results are presented in Table 1.

From this table, it can be seen that:

- A number of the recommendations were issued by nearly all of the organizations. These comprised avoiding outdoor activities that entail a high degree of exposure to pollen, consultation of the pollen forecasts, avoiding drying one's laundry outdoors, and wearing of pollen-protective glasses and a facemask when outdoors;

- A number of the recommendations were issued by most of the organizations. These comprised avoiding all intrusion of pollen into the house, providing explanations about the disease and the symptoms, rinsing one's hair at night, keeping home and car windows closed, avoiding intrusion of pollen, use of pollen filters in the car during periods of pollination;

- Lastly, some of the recommendations were only issued by some of the organizations. These comprised choosing where to go for a walk or on holiday, cleaning the house, use of air purifiers, airing out one's home early in the morning or late at night, abundantly rinsing one's eyes and nostrils with water, avoiding objects that collect pollen, avoiding wearing contact lenses, washing of pets once per week, avoiding walking on the sunny side of the street, and taking into account the humidity of the air.

\section{Evaluation of the Scientific Relevance of the Guidelines}

Below, we review the various recommendations that have been made available to the public, starting with the most often issued guidelines and finishing with the ones that are mentioned less often.

\section{Consultation of Pollen Forecasts (Table 2)}

Allergens are contained within grains of pollen. The level of pollen is, therefore, a good indicator of the quantity of allergen present $[1,2]$. Several recent studies have measured the level of pollen in the atmosphere and compared it to the Symptom Load Index (SLI). The higher the index, the greater the allergen burden is in a population. The degrees of pollination of pollen from birch [3-6], grasses $[3-5,7,8]$, ragweed $[3,6]$, and mugwort $[3,4]$ have been determined in this manner in Europe. Studies undertaken in Atlanta (GA, USA) [9], Porto (Portugal) [10], and Wake County (NC, USA) [11] have compared the concentration of pollen in the atmosphere and the number of emergency ward consultations for asthma attacks or for lower respiratory symptoms, and they concluded that there is a positive correlation between these 2 parameters. In a Finnish study, there was a correlation between the level of pollen in the air and the level of pollen found in the nostrils of individuals during the time of peak pollination [12]. The graph representing the doseeffect relationship had a sigmoidal shape, with a threshold under which no symptoms were observed, followed by a linear dose-effect relationship, and then a plateau above which the symptoms did not increase despite the increase in the level of pollen in the air [13]. An exception to this is a study carried out in Germany and Austria, in which the authors did not find a correlation between the symptoms and the quantity of pollen in the air [6]. For the most part, these studies allow it to be concluded that it is important for allergic patients to consult the pollen forecasts so as to make adjustments in regard to their outings, whether or not to take their allergy medication, or to simply prepare themselves for the to be expected allergic symptoms.

\section{Avoiding Outdoor Activities That Entail a High \\ Degree of Exposure to Pollens}

The spectrum of pollens found indoors corresponds with that found outdoors. Data in this regard have been obtained from pollen collectors that were located outdoors and indoors at hospitals in Badajoz (Spain) [14] and in Naples (Italy) [1]. In Vienna (Austria), the level of 


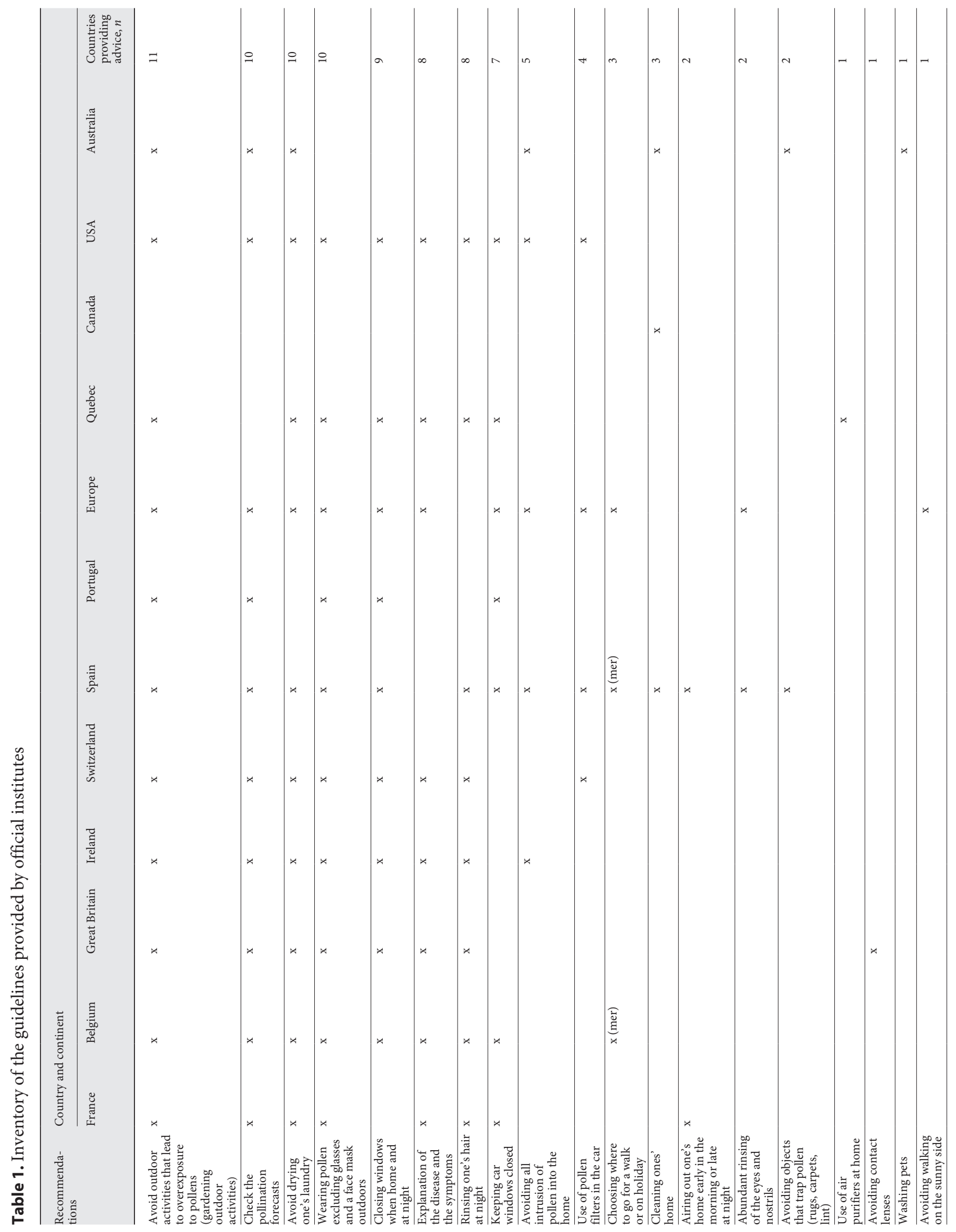



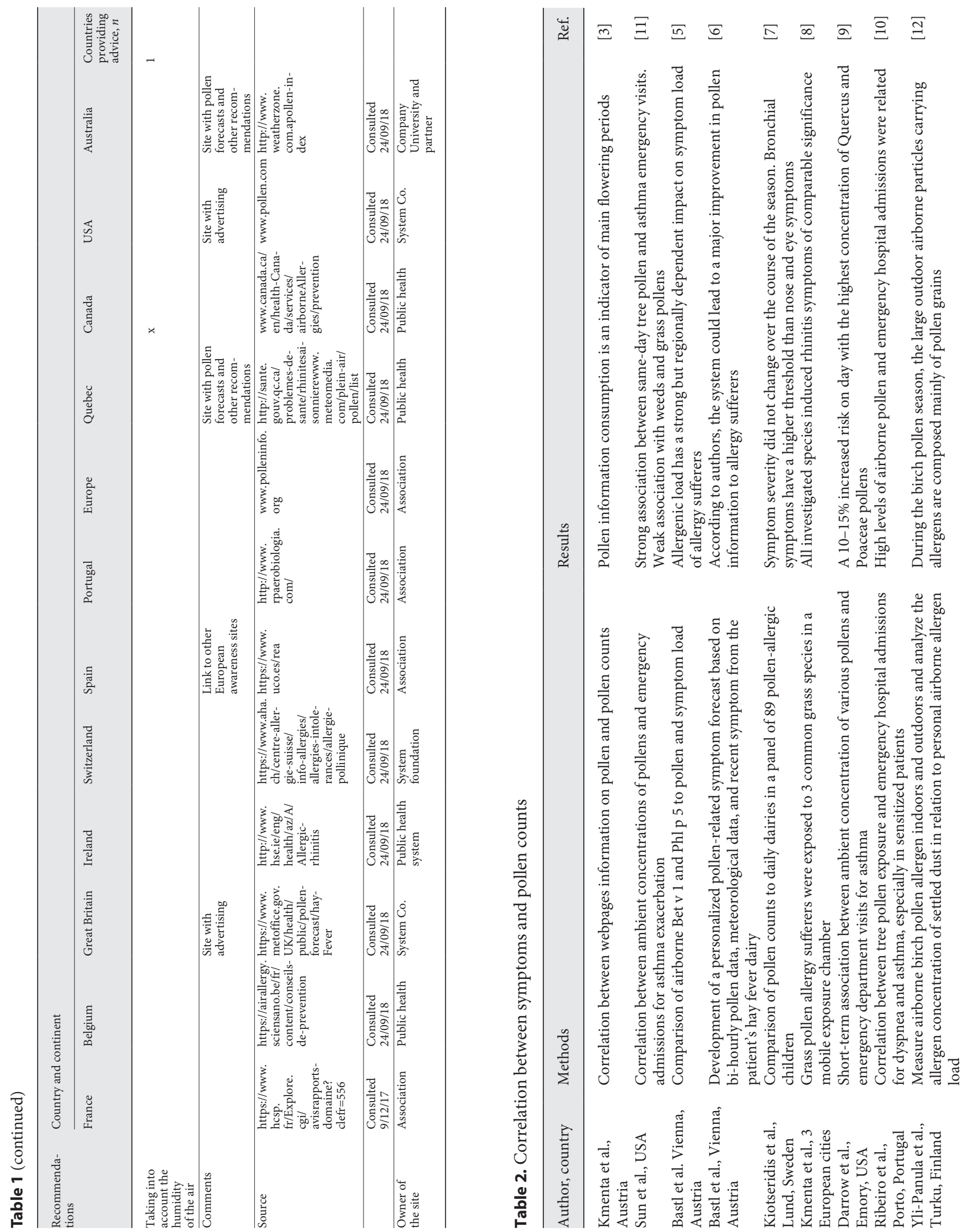
Table 3. Comparison of indoor and outdoor pollen counts

\begin{tabular}{|c|c|c|c|}
\hline Author, country & Methods & Results & Ref. \\
\hline $\begin{array}{l}\text { D'Amato et al., Naples } \\
\text { Italy }\end{array}$ & $\begin{array}{l}\text { Simultaneous measurement of Parietaria pollens and } \\
\text { allergens at the allergy service with the balcony opened } \\
\text { or closed and relative to the background pollen count }\end{array}$ & $\begin{array}{l}\text { With the balcony open, few difference between outdoor and } \\
\text { indoor allergenic activity, but reduction of one-third when } \\
\text { balcony closed }\end{array}$ & {$[1]$} \\
\hline $\begin{array}{l}\text { Yli-Panula et al., Turku, } \\
\text { Finland }\end{array}$ & $\begin{array}{l}\text { Measure airborne birch pollen allergen indoors and } \\
\text { outdoors and analyze the allergen concentration of } \\
\text { settled dust in relation to personal airborne allergen } \\
\text { load }\end{array}$ & $\begin{array}{l}\text { During the birch pollen season, the large outdoor airborne } \\
\text { particles carrying allergens are composed mainly of pollen } \\
\text { grains }\end{array}$ & {$[12]$} \\
\hline $\begin{array}{l}\text { Tormo-Molina et al., } \\
\text { Badajoz, Spain }\end{array}$ & $\begin{array}{l}\text { Monitoring of indoor pollen in a hospital over } 2 \text { years } \\
\text { in } 4 \text { places: } 1 \text { closed room, } 2 \text { open wards, and } 1 \text { place } \\
\text { outdoors at the entrance of the hospital }\end{array}$ & $\begin{array}{l}\text { Average pollen concentration } 10 \text { times lower indoor. Strong } \\
\text { seasonal pattern indoor and correlation with outdoor } \\
\text { measurements. Indoor results not influenced by floor level, } \\
\text { room opened or closed }\end{array}$ & {$[14]$} \\
\hline $\begin{array}{l}\text { Menzel et al., Munich, } \\
\text { Germany }\end{array}$ & $\begin{array}{l}\text { Hourly measurement of birch pollen indoor during } 8 \\
\text { days in } 5 \text { rooms and comparison with outdoor values } \\
\text { in the front of the rooms and to background pollen } \\
\text { data }\end{array}$ & $\begin{array}{l}\text { Mean indoor/outdoor ratio was highest in a room with fully } \\
\text { opened window and a mechanical ventilation, followed by } \\
\text { rooms with fully opened windows and lowest in neighboring } \\
\text { rooms with titled windows }\end{array}$ & {$[16]$} \\
\hline $\begin{array}{l}\text { Hugg and Rantio- } \\
\text { Lehtimäki, South } \\
\text { Karelia and Turku, } \\
\text { Finland }\end{array}$ & $\begin{array}{l}\text { Betula pollen concentrations measured during the } \\
\text { pollen season inside and outside a block of flats, a } \\
\text { detached house, and a regional hospital }\end{array}$ & $\begin{array}{l}\text { Concentrations of Betula pollens decreased from outdoors to } \\
\text { indoors, and further toward the center of the building }\end{array}$ & [17] \\
\hline $\begin{array}{l}\text { Lee et al., Cincinnati, } \\
\text { USA }\end{array}$ & $\begin{array}{l}\text { Air sampling inside and outside of } 6 \text { single-family } \\
\text { homes during } 3 \text { seasons }\end{array}$ & Indoor pollen concentration was 50 -fold lower than outdoors & {$[18]$} \\
\hline $\begin{array}{l}\text { MacIntosh, Boston, } \\
\text { USA }\end{array}$ & $\begin{array}{l}\text { Evaluate, through a modeling analysis, the benefit of } \\
\text { whole-house in-duct air cleaning exposures to fine } \\
\text { particulate matter of outdoor origin }\end{array}$ & $\begin{array}{l}\text { The potential health benefits were evaluated as "substantial." } \\
\text { Mean } 24 \text {-h average indoor to outdoor ratio of ambient PM2.5 } \\
\text { was } 0.57 \text { for homes with natural ventilation and } 0.1 \text { for homes } \\
\text { with central air cleaning }\end{array}$ & {$[46]$} \\
\hline $\begin{array}{l}\text { Jantunen et al., } \\
\text { Laakarite, Finland }\end{array}$ & $\begin{array}{l}\text { The importance of pollen transportation into houses } \\
\text { was evaluated using } 6-8 \text { simultaneously collecting } \\
\text { Rotorod-type samplers }\end{array}$ & $\begin{array}{l}\text { The indoor/outdoor ratio decreased as the distance from the } \\
\text { ventilation opening increased. Efficient ventilation with } 2 \\
\text { open windows increased the indoor/outdoor ratio and enabled } \\
\text { pollen to spread }\end{array}$ & [22] \\
\hline $\begin{array}{l}\text { Takahashi et al., } \\
\text { Wakayama, Japan }\end{array}$ & $\begin{array}{l}\text { Measure the amount of pollen allergen adhering to } \\
\text { fabrics outdoors. Study of the effect of ventilation } \\
\text { conditions on pollen entering indoors }\end{array}$ & $\begin{array}{l}\text { More than half of pollen remained on the fabric surface after } \\
\text { being brushed off by hand or shaken. Most pollen entered by } \\
\text { ventilation remained near the window }\end{array}$ & {$[48]$} \\
\hline
\end{tabular}

pollen was measured over 4 non-consecutive days in 2015 and 2016 [15]. In 2015, at the site of the Technical University in Munich (Germany), the pollen from birch was measured over 8 days during the time that this type of tree pollinates [16]. In Lappeenranta (Finland), pollen was collected outdoors at entry doors and indoors away from openings, in individual houses, apartment blocks, and a hospital [17]. In Cincinnati (USA), measurements were taken 3 times in a year over a 24 -h period, both outdoors and in 6 individual family homes [18]. Outdoor and indoor measurements at the university in Cordoba (Spain) were compared during work hours [19]. Despite the different activities at the various sites, the levels of pollen were higher outdoors than indoors (Table 3). It was during the times of peak pollination, that is to say when the external concentrations of pollen were highest, that the reduction in the proportion of the pollen concentration indoors was most pronounced. All in all, the studies are unanimous in their conclusion that during the pollina-

Evaluation of the Recommendations for Patients with Pollen Allergies tion season, the outdoor concentration of pollen is considerably higher than the indoor concentration.

\section{Avoiding Drying One's Laundry Outdoors}

The allergens contained in grains of pollen come into contact with the mucous membranes of the eyes and the mucosal layers of the upper respiratory tract by passing through the oral and nasal cavities [27]. This recommendation assumes that pollen that settles on laundry items remains significantly attached. The identification of pollen is used in legal medicine, such as investigation of whether the pollen found on the clothes of the accused corresponds with the pollen found on the clothes of the victim and of the last place that they visited [20]. Pollen adheres spontaneously to clothes $[21,22]$. In Taiwan, pollen was analyzed on the T-shirt of a hiker after he had gone on 1-h walks at various locations [21]. Once attached, it takes time for pollen to detach. Pollen was found on the clothing of a cadaver dating back to the first cen- 
Table 4. Protective effects of face masks and eyeglasses

\begin{tabular}{|c|c|c|c|}
\hline $\begin{array}{l}\text { Author, } \\
\text { country }\end{array}$ & Methods & Results & Ref. \\
\hline $\begin{array}{l}\text { Comert et al., } \\
\text { Ankara, Turkey }\end{array}$ & $\begin{array}{l}70 \text { patients with seasonal allergic rhinitis were randomized } \\
\text { to receive either wraparound eyeglass plus treatment or } \\
\text { treatment alone. Efficacy was rated on symptoms and } \\
\text { quality-of-life questionnaire }\end{array}$ & $\begin{array}{l}\text { Nasal and ocular symptoms were significantly lower when } \\
\text { wearing eyeglasses. Then, quality-of-life score was higher and } \\
\text { there was less need for rescue medication }\end{array}$ & [28] \\
\hline $\begin{array}{l}\text { Ozturk et al., } \\
\text { Ankara, Turkey }\end{array}$ & $\begin{array}{l}39 \text { patients with a history of seasonal allergic rhinitis were } \\
\text { randomized to sunglasses during day time plus medication } \\
\text { or medication alone. The study lasted } 4 \text { weeks }\end{array}$ & $\begin{array}{l}\text { Sunglasses significantly reduced ocular symptoms and use of } \\
\text { antihistamines }\end{array}$ & [29] \\
\hline $\begin{array}{l}\text { Kenney et al., } \\
\text { Aarhus, } \\
\text { Denmark }\end{array}$ & $\begin{array}{l}\text { This randomized, double-blind, placebo-controlled, cross- } \\
\text { over study was conducted during } 2 \text { days in the pollen season } \\
\text { to assess the efficacy of nasal filters (Rhinix, Aarhus, } \\
\text { Denmark) }\end{array}$ & $\begin{array}{l}\text { The nasal filters reduced the total daily symptom score by } 40 \% \\
\text { and the eyes symptoms by } 75 \% \text {. They were well tolerated }\end{array}$ & [30] \\
\hline $\begin{array}{l}\text { D'Amato et al., } \\
\text { Naples, Italy }\end{array}$ & $\begin{array}{l}\text { Open clinical study investigating use of a nasal filter } \\
\text { (Sanispira) in a group of Parietaria pollen allergic patients }\end{array}$ & $\begin{array}{l}\text { Scores of nasal symptoms and use of antihistaminic drugs were } \\
\text { reduced in patients using nasal filters }\end{array}$ & [31] \\
\hline $\begin{array}{l}\text { Gotoh et al., } \\
\text { Chiba, Japan }\end{array}$ & $\begin{array}{l}\text { Test the usefulness of a face mask and eyeglasses in a study } \\
\text { including volunteers }\end{array}$ & $\begin{array}{l}\text { The number of pollen particles in the nasal cavity and on the } \\
\text { conjunctiva was unchanged by wearing a face mask and } \\
\text { eyeglasses. However, the pollen invasion rate in the nasal cavity } \\
\text { was lower }\end{array}$ & [32] \\
\hline $\begin{array}{l}\text { Morishima et } \\
\text { al., Nagano, } \\
\text { Japan }\end{array}$ & $\begin{array}{l}\text { Survey performed in } 1,519 \text { university students in Japan } \\
\text { about the use of commercially available facemasks for } \\
\text { prevention of hay fever symptoms }\end{array}$ & $\begin{array}{l}\text { Almost all users reported problems, male users "humidity" and } \\
\text { "occurrence of mist over glasses," females "ruining make-up" }\end{array}$ & [33] \\
\hline
\end{tabular}

tury AD [23]. The quantity of pine pollen on cotton worn by individuals decreases exponentially: $17 \%$ of the initial quantity remains after 14 days [24]. More than half of the pollen can be removed by rinsing or by shaking the fabric [25]. Some studies have sought to differentiate fabrics used for clothes according to their capacity to capture different pollens $[25,26]$. Pollens adhere more to fabrics that are granular in nature (e.g., cotton, jeans, and fleece). These studies confirm that fabrics used for clothing accumulate pollens. Not all of the pollen can be removed, however, by shaking or by rinsing the item. It seems likely that allergens are removed by rinsing clothes, as extraction with water is the common way to extract allergens. There have, however, been no studies to date to confirm this hypothesis.

\section{Wearing Pollen-Protective Glasses and a Face Mask When Outdoors (Table 4)}

The efficacy of pollen-protective glasses has been evaluated in 2 studies. One of these took place over 3 consecutive years [28], and the other lasted 1 year [29]. The included patients all suffered from seasonal allergic rhinoconjunctivitis and were randomly assigned to 2 groups that did or did not wear pollen-protective glasses. Both studies concluded that there was a significant improvement in ocular symptoms and a decrease in the use of medication in the group that wore the protective glasses. The study by Kenney et al. [30] investigated the efficacy of a nasal filter. Sixty-five patients afflicted with rhinoconjunctivitis were observed over 2 days during the pollination period of grasses in Denmark in 2014. Use of the nasal filter was associated with a reduction of the allergy symptoms in the users [30]. A study carried out in Naples (Italy) reached the same conclusion [31]. Simultaneous use of a surgical mask and glasses was investigated in Japan. The quantity of pollen in eye and nasal washes was measured in healthy volunteers with or without these mechanical barriers. The number of pollen particles in the air was the same, but the level of invasion of pollen was lower when a mask and glasses were worn [32]. These barriers are, therefore, effective but not sufficient to eliminate exposure to pollen. Some patients used medications despite also wearing a mask and glasses [33]. Thus, masks and glasses are mechanical means that are simple, inexpensive, and partially effective at reducing symptoms.

\section{Rinsing One's Hair at Night}

Studies in the medico-legal area have shown that hair can trap pollen [34]. Rinsing the hair of a cadaver allows the majority of the pollen particles to be collected [35]. Archeological studies have proven the longevity of pollen. For example, pollen could be analyzed from a cadaver dating back to more than 3,000 years BC [36]. The capacity of hairs to trap pollen stems, among other things, from their electrostatic properties. Hair tends to attract light particles [37]. A study performed in France, in Mar- 
Table 5. Pollination and time of day

\begin{tabular}{|c|c|c|c|}
\hline Author, country & Methods & Results & Ref. \\
\hline $\begin{array}{l}\text { Jones et al., } \\
\text { Stillwater, USA }\end{array}$ & $\begin{array}{l}\text { Pollen trap made with microscope } \\
\text { and petroleum jelly film }\end{array}$ & $\begin{array}{l}\text { The time of day of shedding varied widely for the different species and appeared to be } \\
\text { controlled by factors inherent in each species }\end{array}$ & {$[39]$} \\
\hline $\begin{array}{l}\text { Uguz et al., Izmir, } \\
\text { Turkey }\end{array}$ & Volumetric trap/Spearman's test & During the study, the intradiurnal distribution of the pollen varied & {$[40]$} \\
\hline $\begin{array}{l}\text { Ribeiro et al., Porto, } \\
\text { Portugal }\end{array}$ & $\begin{array}{l}\text { Volumetric Hirst trap/non-linear } \\
\text { logistic regression }\end{array}$ & $\begin{array}{l}\text { Pollen with morning shedding: Urticaceae, Cupressaceae, Acer spp., and Plantago spp. } \\
\text { Pollen with afternoon shedding: Alnus spp. and Betula spp. } \\
\text { Pollen with regular shedding along the day: Olea europaea and Platanus spp. pollen }\end{array}$ & {$[41]$} \\
\hline $\begin{array}{l}\text { Simoleit et al., } \\
\text { Lemwerder, } \\
\text { Germany }\end{array}$ & Volumetric Hirst-type trap & $\begin{array}{l}\text { Main grass pollen period: 8:00 a.m. to 10:00 p.m. } \\
\text { Main mugwort pollen period: 6:00 a.m. and 2:00 p.m. }\end{array}$ & {$[42]$} \\
\hline $\begin{array}{l}\text { Borycka et al., } \\
\text { Rzeszow, Poland }\end{array}$ & $\begin{array}{l}\text { Hirst volumetric spore trap/ } \\
\text { circular statistics and a nonlinear } \\
\text { function }\end{array}$ & $\begin{array}{l}\text { High birch and alder pollen concentrations all day long day except morning hours } \\
\text { and the first hours of precipitation }\end{array}$ & {$[43]$} \\
\hline $\begin{array}{l}\text { Laaidi et al., Dijon, } \\
\text { France }\end{array}$ & Hirst trap & $\begin{array}{l}\text { Trees with nocturnal pollen shedding: ash, poplar, birch, oak, chestnut, pine } \\
\text { Trees with afternoon pollen shedding: hazel alder, Cupressaceae-Taxaceae, willow, } \\
\text { charm, plane tree }\end{array}$ & {$[44]$} \\
\hline
\end{tabular}

seille and in Valence, in 2008, showed that pollens taken from the hair of 20 healthy volunteers corresponded to the outdoor pollens that the individuals had been exposed to. That is to say, the pollens corresponded to their personal exposures [38]. Thus, hair constitutes a pollen trap, and as a result of the proximity to the nasal mucosa, rinsing one's hair should allow for a reduction in the exposure to pollen.

\section{Airing Out One's Home Early in the Morning and Late at Night (Table 5)}

Several studies have measured the diurnal variations in outdoor pollen, using 1 or several Hirst-type volumetric collectors manufactured by companies such as Burkard and Lanzoni. The locations of the collectors varied between the studies. The collection periods ranged from 7 days to an entire year. These publications were in regard to measurements taken after the 2000s, except for the study from 1945 onward in the USA [39]. The latter study, the oldest one found, describes 35 pollens, each of which dispersed according to their own timing; the common element being that this dispersion only occurred during the day. Generally, the publications found high pollen concentrations at midday and low concentrations at night, based on sampling in Turkey, Portugal, and Germany [40-42]. A number of studies presented the measurement of a particular pollen, but the results are not consistent. In Poland and Portugal, birch pollen exhibited a peak of dispersion at night [43] and in the evening [41]. In Germany, in the vicinity of a freeway, the peak dispersion oc-

Evaluation of the Recommendations for Patients with Pollen Allergies curred in the afternoon [42]. In France, birch pollen was found to be released continuously throughout the diurnal cycle [44]. It is hence very unlikely that there is a time during the day when opening the windows does not entail a degree of risk for all allergic patients. For patients who are not allergic to a broad range of pollens, there should be times that are suitable for opening the windows based on the timing of the diurnal dispersion of the pollens that they are allergic to.

\section{Closing the Windows at Home and at Night/Keeping Car Windows Closed (Table 6)}

Two studies compared the outdoor and indoor pollens at hospitals sites in Japan and Italy. These studies concluded that pollen present indoors is transported by the air through openings (doors and windows) [1,45]. In other studies, the indoor pollen was measured under different conditions, according to whether the doors and windows were open or closed. Rooms with a greater number of windows were found to have higher levels of pollen [1, $16,46-48]$. The concentrations of birch and pine pollens decreased as the distance between the pollen collector and the window increased [12, 47]. A number of studies have found that the concentration of pollen in a car's passenger compartment correlates with the outdoor concentration of pollen. Although the concentration of pollen inside was half that of the outside concentration, it was high enough to lead to symptoms in allergic patients $[49,50]$. Opening the windows increased the level of pollen inside the passenger compartment, particularly for the front 
Table 6. Routes of entering of pollen into the house

\begin{tabular}{|c|c|c|c|}
\hline Author, country & Methods & Results & Ref. \\
\hline $\begin{array}{l}\text { D’Amato et al., } \\
\text { Naples, Italy }\end{array}$ & $\begin{array}{l}\text { Simultaneous measurement of Parietaria pollens and } \\
\text { allergens at the allergy service with the balcony opened } \\
\text { or closed and relative to the background pollen count }\end{array}$ & $\begin{array}{l}\text { With the balcony open, few difference between outdoor and indoor } \\
\text { allergenic activity, but reduction of one-third when balcony closed }\end{array}$ & {$[1]$} \\
\hline $\begin{array}{l}\text { Menzel et al., } \\
\text { Munich, } \\
\text { Germany }\end{array}$ & $\begin{array}{l}\text { Hourly measurement of birch pollen indoor during } 8 \\
\text { days in } 5 \text { rooms and comparison with outdoor values } \\
\text { in the front of the rooms and to background pollen } \\
\text { data }\end{array}$ & $\begin{array}{l}\text { Mean indoor/outdoor ratio was highest in a room with fully opened } \\
\text { window and a mechanical ventilation, followed by rooms with fully } \\
\text { opened windows and lowest in neighboring rooms with titled } \\
\text { windows }\end{array}$ & {$[16]$} \\
\hline $\begin{array}{l}\text { MacIntosh, } \\
\text { Boston, USA }\end{array}$ & $\begin{array}{l}\text { Evaluate, through a modeling analysis, the benefit of } \\
\text { whole-house in-duct air cleaning exposures to fine } \\
\text { particulate matter of outdoor origin }\end{array}$ & $\begin{array}{l}\text { The potential health benefits were evaluated as "substantial." Mean } \\
\text { 24-h average indoor to outdoor ratio of ambient PM2.5 was } 0.57 \text { for } \\
\text { homes with natural ventilation and } 0.1 \text { for homes with central air } \\
\text { cleaning }\end{array}$ & {$[46]$} \\
\hline $\begin{array}{l}\text { Takahashi et al., } \\
\text { Wakayama, Japan }\end{array}$ & $\begin{array}{l}\text { Measure the amount of pollen allergen adhering to } \\
\text { fabrics outdoors. Study of the effect of ventilation } \\
\text { conditions on pollen entering indoors }\end{array}$ & $\begin{array}{l}\text { More than half of pollen remained on the fabric surface after being } \\
\text { brushed off by hand or shaken. Most pollen entered by ventilation } \\
\text { remained near the window }\end{array}$ & {$[48]$} \\
\hline $\begin{array}{l}\text { Holmquist et al., } \\
\text { Stockholm, } \\
\text { Sweden }\end{array}$ & $\begin{array}{l}\text { Measurement of pollen allergens in street-level shops } \\
\text { and evaluation of effect of an electrostatic air cleaner }\end{array}$ & $\begin{array}{l}\text { Substantial amounts of pollen allergen recovered. The air cleaner } \\
\text { reduced the birch pollen allergens by } 32 \% \text { and the grass pollen } \\
\text { allergens by } 18 \%\end{array}$ & [49] \\
\hline $\begin{array}{l}\text { Hugg et al., South } \\
\text { Karelia and } \\
\text { Turku, Finland }\end{array}$ & $\begin{array}{l}\text { Betula pollen concentrations measured during the } \\
\text { pollen season inside and outside a block of flats, a } \\
\text { detached house, and a regional hospital }\end{array}$ & $\begin{array}{l}\text { Concentrations of Betula pollens decreased from outdoors to } \\
\text { indoors, and further toward the center of the building }\end{array}$ & {$[50]$} \\
\hline
\end{tabular}

seats [51]. Thus, closing the windows is an effective measure to reduce the level of pollen inside a car.

\section{Avoiding All Intrusion of Pollen into the House \\ (Table 7)}

During periods of pollination, the quantity of indoor pollens correlates with the quantity outdoors $[1,15,16$, 18]. As seen previously, openings and items that capture pollen, such as pets and fabrics, are vectors that tend to increase the concentration of indoor pollens. There are, however, a number of other factors. Even when the windows are kept closed, pollen can enter through air vents, and a large quantity of pollen can typically be found in their vicinity [48]. Human activities influence the quantity of indoor pollen. A person walking into a room generally causes the pollen in the room to become dispersed [52]. Studies in Germany and Sweden have reported that the quantity of pollen was higher in rooms accommodating children than in rooms accommodating adults, as children tend to be more active $[53,54]$. On the other hand, in the lobby of the hospital of Badajoz in Spain, the level of indoor pollen did not correlate with the number of people who entered [14]. Indoor plants diffuse pollens [14], and in a closed room, the concentration of pollen increases the closer one gets to a plant. When the plant is removed, the pollen persists, however [55]. Thus, interventions targeting the various vectors that allow the intrusion of pollen into the home generally reduce the concentration of indoor pollen.

\section{Use of Home Air Purifiers/Use of Car Pollen Filters}

A handbook [56] provides the basic theories and science behind the technical solutions. There are several interventional studies in the literature that compared various types of ventilation. A review of the literature examined 4 types of ventilation separately or in combination [57]. The HVAC (Heating, Ventilation, Air Conditioning) system involves ventilation that works both as heating and air conditioning. WHF (Whole House Filtration) is a system that filters all of the air in the house. HEPA (High-Efficiency Particulate Air) is a high-efficiency particulate filter. PRAC (Portable Room 
Table 7. Avoiding intrusion of pollen into the house

\begin{tabular}{|c|c|c|c|}
\hline Author, country & Methods & Results & Ref. \\
\hline $\begin{array}{l}\text { D'Amato et al., Naples, } \\
\text { Italy }\end{array}$ & $\begin{array}{l}\text { Simultaneous measurement of Parietaria pollens and } \\
\text { allergens at the allergy service with the balcony opened } \\
\text { or closed and relative to the background pollen count }\end{array}$ & $\begin{array}{l}\text { With the balcony open, few difference between outdoor and } \\
\text { indoor allergenic activity, but reduction of one-third when } \\
\text { balcony closed }\end{array}$ & {$[1]$} \\
\hline $\begin{array}{l}\text { Tormo-Molina et al., } \\
\text { Badajoz, Spain }\end{array}$ & $\begin{array}{l}\text { Monitoring of indoor pollen in a hospital over } 2 \text { years } \\
\text { in } 4 \text { places: } 1 \text { closed room, } 2 \text { open wards, and } 1 \text { place } \\
\text { outdoors at the entrance of the hospital }\end{array}$ & $\begin{array}{l}\text { Average pollen concentration } 10 \text { times lower indoor. Strong } \\
\text { seasonal pattern indoor and correlation with outdoor } \\
\text { measurements. Indoor results not influenced by floor level, } \\
\text { room opened or closed }\end{array}$ & {$[14]$} \\
\hline $\begin{array}{l}\text { Bastl et al., Vienna, } \\
\text { Austria }\end{array}$ & $\begin{array}{l}\text { Assessment of pollen content in the air, floor dust and } \\
\text { desktops of an office, and outdoors. Sampling in } \\
\text { winter (reference day) and during pollination of } \\
\text { Betula, Poaceae, and Ambrosia }\end{array}$ & $\begin{array}{l}\text { Airborne pollen concentration was generally lower indoors } \\
\text { but showed associations with dust by containing } \\
\text { nonseasonal pollen types as well as seasonal pollens }\end{array}$ & {$[15]$} \\
\hline $\begin{array}{l}\text { Menzel et al., Munich, } \\
\text { Germany }\end{array}$ & $\begin{array}{l}\text { Hourly measurement of birch pollen indoor during } 8 \\
\text { days in } 5 \text { rooms and comparison with outdoor values } \\
\text { in the front of the rooms and to background pollen } \\
\text { data }\end{array}$ & $\begin{array}{l}\text { Mean indoor/outdoor ratio was highest in a room with fully } \\
\text { opened window and a mechanical ventilation, followed by } \\
\text { rooms with fully opened windows and lowest in neighboring } \\
\text { rooms with titled windows }\end{array}$ & {$[16]$} \\
\hline $\begin{array}{l}\text { Lee et al., Cincinnati, } \\
\text { USA }\end{array}$ & $\begin{array}{l}\text { Air sampling inside and outside of } 6 \text { single-family } \\
\text { homes during } 3 \text { seasons }\end{array}$ & $\begin{array}{l}\text { Indoor pollen concentration was } 50 \text {-fold lower than } \\
\text { outdoors }\end{array}$ & [18] \\
\hline $\begin{array}{l}\text { Takahashi et al., } \\
\text { Wakayama, Japan }\end{array}$ & $\begin{array}{l}\text { Measure the amount of pollen allergen adhering to } \\
\text { fabrics outdoors. Study of the effect of ventilation } \\
\text { conditions on pollen entering indoors }\end{array}$ & $\begin{array}{l}\text { More than half of pollen remained on the fabric surface after } \\
\text { being brushed off by hand or shaken. Most pollen entered } \\
\text { by ventilation remained near the window }\end{array}$ & [48] \\
\hline $\begin{array}{l}\text { Fahlbusch et al., } \\
\text { Hamburg, Erfurt, } \\
\text { Hettstedt, Zerbst, and } \\
\text { Bitterfeld }\end{array}$ & $\begin{array}{l}\text { Quantify the amount of grass pollen allergen in dust } \\
\text { settled indoors and detect the distribution of allergen } \\
\text { in different sampling locations in homes and different } \\
\text { seasons. 1,500 randomly selected homes }\end{array}$ & $\begin{array}{l}\text { Phlp5 was detected in } 67 \% \text { of the } 47 \text { samples analyzed. } \\
\text { Higher concentration in living rooms and bedrooms than in } \\
\text { mattresses. Considerable high level of Phlp5 in indoor dust, } \\
\text { even outside of the grass pollen season }\end{array}$ & [53] \\
\hline $\begin{array}{l}\text { Holmquist et al., } \\
\text { Stockholm, Sweden }\end{array}$ & $\begin{array}{l}\text { Quantification of Betula and Poaceae allergens in } 2 \\
\text { school rooms and } 2 \text { office rooms }\end{array}$ & $\begin{array}{l}\text { Both groups of rooms carried substantial amount of pollen } \\
\text { allergens. In } 1 \text { school room, high short-term increase in the } \\
\text { presence of children }\end{array}$ & {$[54]$} \\
\hline
\end{tabular}

Air Cleaner) is a portable air purifier. The study concluded that, provided that they were well maintained, the use of HVAC + WHF devices allowed the symptoms of allergic individuals to be reduced and was more efficient than the individual HEPA + PRAC association. The general review by Fisk [58] examined 16 studies that took place in dwellings and hospitals. These studies concluded that there was a moderate improvement in symptoms in terms of allergies to pets. Three reviews to date have compiled studies comparing HEPA to a placebo [59-61]. These concluded that HEPA is effective at reducing the number of particles in the air, but there was no sign of an improvement in clinical symptoms. By contrast, an experimental study that involved placing people suffering from allergic rhinitis in front of an air purifier fed with pollens revealed a reduction in symptoms when an air filter for grass pollens was used [62]. Another study concluded that membrane-type pollen filters are effective. This type of filter allowed for a decrease of approximately $80 \%$ in the concentrations of pollen of Poaceae and Cupressaceae-Taxaceae, and of $50 \%$ of Urticaceae [63]. Therefore, these studies suggest that air filters can be partially effective.

Evaluation of the Recommendations for Patients with Pollen Allergies

\section{Choosing Where to Go for a Walk or Where to Go on Holidays}

Coastal, mountainous, and wooded areas are places where the flora differs according to the inherent climatic conditions. Analysis by 53 collectors of pollen situated in 11 mountainous areas in China confirmed that wooded areas in the mountains produce an abundance of pollen [64]. In Spain, pollen was measured at 13 stations distributed throughout the country. The collectors recorded different pollens and distinct periods of pollination [65]. In Japan, a study performed from 1996 to 2006 recorded a level of pollen in the mountains, which was twice as high as on the coast. An increase in nasal symptoms was noted in the pediatric population living in the mountains [66]. On the other hand, a study measuring pollen from 2000 to 2009 at 13 sites in Central Europe and Eastern Europe did not find that there was a geographical variation in mugwort pollen [67]. Furthermore, several studies have reported higher levels in rural than in urban areas [6870]. This can be explained by the denser vegetation in the countryside. Pollen tends to be airborne, and a number of studies have in fact reported a high degree of dispersion over several thousand kilometers [71-73]. Thus, pollen is 
present in coastal, mountainous, and wooded areas, and wind can cause them to be diffused over long distances. Thus, very few places on earth are pollen-free.

\section{Washing Pets}

Pets can be transporters of pollens. Their fur, like clothes, captures pollen. A dog that spent most of the day outdoors was found to have 220-240 grains of birch pollen per square centimeter of fur [22]. Once attached, pollen can stay on an animal for a long time. A study has analyzed the pollens found on the fur and the feathers of prehistoric animals [74]. Analysis of the dust in 459 homes distributed across the USA showed that there was relatively more grass pollen and other taxa in homes that had a dog [75]. Pets are hence vectors that increase the level of indoor pollen.

\section{Keeping the Home Clean}

Pollen is particulate matter with a certain weight. On a given individual, there is generally a gradient of pollen that increases from the head to the feet [22]. Pollen from different visited sites has been shown to accumulate on shoes, although the pollen/spore content dominantly reflects that of the last site [76]. A number of publications have measured the level of indoor pollen by sampling the pollen on the ground with a mop [15]. Pollen is still present in dwellings outside of periods of pollination [53]. In winter, the quantity of indoor pollen is higher than that measured outdoors [15]. The number of grains of pollen is higher on surfaces that are washed the least [17]. In a room where there was continuous diffusion of pollen of Japanese cedar, the quantity of pollen was reduced after it had been washed with tap water, and it was fully removed after it had been washed with distilled water [52]. For people with allergies, it is important to regularly clean the home, as pollens introduced into the dwelling retain their allergenicity over several months or years $[77,78]$.

\section{Abundant Rinsing of One's Eyes and Nostrils}

Grains of pollen can become deposited on the mucosa, thereby triggering an adverse immune response. Samples taken from the nasal cavities of cadavers have revealed pollens corresponding with the location where they died 1 year after their death [34]. In a Finnish study, pollens collected from a cadaver's nasal cavities corresponded to the pollens of where they resided [12]. In another study, pollen was diffused continuously on volunteer allergic patients in a hermetically sealed room, and low levels of the pollen were detected in the nostrils and the eyes. This small amount was nonetheless enough to lead to allergic symptoms after 30 minutes of exposure [52]. According to a number of publications, rinsing of the eyes and the nostrils allows a portion of the pollen to be removed before the allergic reaction can occur.

\section{Avoiding Wearing Contact Lenses}

Wearing contact lenses can lead to general irritation of the eyes [79], thereby rendering them more sensitive and prone to infection [80]. After 1 minute in a wind tunnel testing the diffusion of pollen, a contact lens lost more than $50 \%$ of its hydration and the pollen became stuck to it [81]. A study has examined how a history of allergy affects allergic eye reactions in people who wear contact lenses. This study concluded that seasonal allergy is a risk factor that can lead to complications with contact lenses, and it advised against their use during periods of pollination $[82,83]$.

By contrast, there are also studies in the literature that recommend that allergic patients wear contact lenses, as they provide a physical barrier that blocks the allergen from settling on the ocular mucosa. A study reported that $67 \%$ of the patients wearing daily contact lenses experienced an improvement in symptoms compared to the group wearing monthly lenses [84]. Allergic patients were exposed to pollen diffusion in a sealed chamber. The patients who wore contact lenses exhibited fewer ocular symptoms than the patients without lenses. Lenses with a lubricant and an antihistamine reduced the burning and stinging sensation more than normal lenses [85].

\section{Avoiding Walking on the Sunny Side of the Street}

Sunshine increases the temperature of the ground and other surfaces, which results in a difference in the temperature between the ground and the air. This difference leads to convective movement, with ascending hot air that lifts pollen grains into the air, thereby increasing the level of pollen in the air [86]. According to this study, allergic patients should avoid walking on the sunny side of the street.

\section{Avoiding Items That Trap Pollen}

A multitude of commonly used items have been reported to have significantly different affinities for pollens. Pollens attach poorly to leather, while they attach moderately to paper, latex, and polyester [26], and they attach well to fabrics. Fabrics are usually present in homes as carpets, curtains, and furniture fabrics. The more coarse the fabric, the more that pollens attach to it [25]. A study in Japan measured pollen on the floor, the carpet, the tatami, matting, blinds, and armchairs. All of these items were found to contain pollen during and after the period of pollination. The carpets contained the greatest amount 
[87]. The quantity of pollen on mattresses was measured in 1,635 homes in Germany between 1995 and 1998. This quantity of pollen remained less than that found on the floor, despite the fact that mattresses are harder to clean [53]. With cotton, rinsing and scrubbing only removes $67 \%$ of the pollen initially present [25]. It is hence recommended that allergic patients avoid items that trap pollen, as they constitute a reserve of indoor pollen that can cause symptoms to persist.

\section{Taking into Account the Humidity of the Air}

When it rains or the humidity of the air increases, pollen grains become heavier as they become loaded with water and they fall to the ground, thereby decreasing the quantity of pollen in the air [41]. However, this principle is not upheld in all studies. The following studies found a negative correlation between humidity and the quantity of pollen in outdoor air: in Brussels (Belgium), the variation in all pollens was studied over a period of 33 years [88]; cypress and birch pollens were studied for 8 and 9 years, respectively, in Salamanca and Orense (Spain) $[89,90]$; in Manila (the Philippines), the study was carried out for a year [91]; in Germany, in the vicinity of a freeway, the level of pollen was measured over 7 consecutive days for 3 years in a row [42]; and in the USA in 1945 and in France from 2004 to 2008, precipitation delayed pollination by several hours $[39,92]$. On the other hand, in Poland, between 2014 and 2016, the level of pollen increased in the first $2 \mathrm{~h}$ of precipitation [43]. This disparity is due to the fact that these studies did not investigate the same species of pollen. In Badajoz (Spain), the quantity of pollen from oak correlated negatively with the humidity, while the quantity of grass pollens correlated positively [93]. In Spain, again, the humidity correlated positively with the quantity of pollen in an urban setting, while it correlated negatively with the quantity of pollen in the countryside. The authors reported that this difference was due to other parameters (wind and temperature) that could also influence the concentration of pollen [94]. Indoor humidity does not appear to influence the level of pollen $[95,96]$. In Parma (Italy), no correlation was found between the quantity of outdoor pollen and the humidity [97]. Furthermore, Pérez et al. [98] have suggested that the size of raindrops may be more important than the level humidity per se, with bigger drops removing pollen from the air better than smaller drops. The literature hence presents disparate results. The majority of studies nonetheless show that humidity reduces the level of pollen in the air. Some studies, however, did not find that there was an effect or their results in fact showed the opposite.

Evaluation of the Recommendations for Patients with Pollen Allergies

\section{Conclusions}

The Internet search that was the objective of the first part of this article was non-exhaustive. It provided access to a large amount of data, primarily in developed countries and in different languages. A search by keywords with a search engine yielded numerous results, although most of the sites were popular scientific sites, of varying commercial natures, that contained advertising and that did not cite the sources of the arguments put forward. We only retained what appeared to be official websites. The studies were not selected based on a specific time frame, and they were from 1945 onward. During this period, the meteorological data have changed, as has the distribution of vegetation and urbanization. It is, therefore, difficult to compare the studies with each other. The studies were not selected according to the location either. Our large panel provides information regarding multiple countries as well as several regions within these countries. The data cannot be compared, however, as pollination depends on the climatic conditions, which differed geographically. The results of these studies, which were undertaken at specific sites, are hence hard to extrapolate.

This work indicates that the recommendations around the world aimed at reducing the exposure of allergic patients to pollen are mostly effective in terms of their impact on the concentration of pollens, although a decrease in symptoms following the application of the recommendations has, for the most part, not been investigated to date [59]. Overall, there was not a correlation between the frequency of a recommendation being mentioned and documentation of the efficacy of the recommendation. The guidelines provided by official institutes to allergic patients aimed at reducing their exposure are straightforward and applicable in everyday life.

This update has allowed it to be shown that the following recommendations based on environmental studies are well-founded: checking pollination forecasts, avoiding outdoor activities, avoiding drying laundry outdoors, closing windows when home at night, keeping car windows closed, wearing pollen-restricting glasses and a face mask, rinsing one's eyes and nostrils, cleaning one's home, avoiding all objects that trap pollen, washing pets, avoiding all intrusion of pollen into the home, and using air purifiers in the home and pollen filters in the car. Proof of a beneficial effect on human health was not investigated. To apply the recommendations regarding airing out of one's home, the period of dispersion of the pollen to which one is sensitive needs to be known, and the home aired out accordingly. The following guidelines

Int Arch Allergy Immunol 2020;181:839-852 849 
have not been validated: avoiding walking on the sunny side of the street and choosing where to go for a walk or on holidays.

\section{Statement of Ethics}

The authors have no ethical conflicts to disclose.

\section{Conflict of Interest Statement}

The authors declare no conflicts of interest.

\section{Author Contributions}

S.R. performed the Internet search and wrote a draft paper. J.P.B., D.B., and M.T. reviewed the manuscript. D.C. initiated the project, participated to the Internet search, and finalized and submitted the manuscript.

\section{References}

1 D’Amato G, Russo M, Liccardi G, Saggese M, Gentili M, Mistrello G, et al. Comparison between outdoor and indoor airborne allergenic activity. Ann Allergy Asthma Immunol. 1996; 77(2):147-52.

2 Buters JT, Weichenmeier I, Ochs S, Pusch G, Kreyling W, Boere AJ, et al. The allergen Bet $\mathrm{v} 1$ in fractions of ambient air deviates from birch pollen counts. Allergy. 2010;65(7):850-

3 Kmenta M, Zetter R, Berger U, Bastl K. Pollen information consumption as an indicator of pollen allergy burden. Wien Klin Wochenschr. 2016;128(1-2):59-67.

4 Berger U, Karatzas K, Jaeger S, Voukantsis D, Sofiev M, Brandt O, et al. Personalized pollenrelated symptom-forecast information services for allergic rhinitis patients in Europe. Allergy. 2013;68(8):963-5.

5 Bastl K, Kmenta M, Pessi AM, Prank M, Saarto A, Sofiev M, et al. First comparison of symptom data with allergen content (Bet $\mathrm{v} 1$ and Phl p 5 measurements) and pollen data from four European regions during 20092011. Sci Total Environ. 2016;548-549(4): 229-35.

6 Bastl K, Kmenta M, Jäger S, Bergmann K-C, Berger U. Development of a symptom load index: enabling temporal and regional pollen season comparisons and pointing out the need for personalized pollen information. Aerobiologia. 2014;30(1):269-80.

7 Kiotseridis H, Cilio CM, Bjermer L, Tunsäter A, Jacobsson H, Dahl A. Grass pollen allergy in children and adolescents-symptoms, health related quality of life and the value of pollen prognosis. Clin Transl Allergy. 2013; 3(1):19.

8 Kmenta M, Bastl K, Kramer MF, Hewings SJ, Mwange J, Zetter R, et al. The grass pollen season 2014 in Vienna: a pilot study combining phenology, aerobiology and symptom data. Sci Total Environ. 2016;566-567:1614-20.

9 Darrow LA, Hess J, Rogers CA, Tolbert PE, Klein M, Sarnat SE. Ambient pollen concentrations and emergency department visits for asthma and wheeze. J Allergy Clin Immunol. 2012;130(3):630-e4.
10 Ribeiro H, Oliveira M, Ribeiro N, Cruz A, Ferreira $\mathrm{A}$, Machado $\mathrm{H}$, et al. Pollen allergenic potential nature of some trees species: a multidisciplinary approach using aerobiological, immunochemical and hospital admissions data. Environ Res. 2009;109(3):328-33.

11 Sun X, Waller A, Yeatts KB, Thie L. Pollen concentration and asthma exacerbations in wake County, North Carolina, 2006-2012. Sci Total Environ. 2016;544(2):185-91.

12 Yli-Panula E. Birch pollen allergen exposure: profiles, sources and characteristics. Settled dust and aeroallergens in indoor and outdoor environments of Finnish homes. Aerobiologia. 2012;28(4):453-65.

13 Durham SR, Nelson HS, Nolte H, Bernstein DI, Creticos PS, Li Z, et al. Magnitude of efficacy measurements in grass allergy immunotherapy trials is highly dependent on pollen exposure. Allergy. 2014;69(5):617-23.

14 Tormo-Molina R, Gonzalo-Garijo A, SilvaPalacios I, Fernández-Rodríguez S. Seasonal and spatial variations of indoor pollen in a hospital. Int J Environ Res Public Health. 2009;6(12):3169-78.

15 Bastl K, Berger U, Kmenta M, Weber M. Is there an advantage to staying indoors for pollen allergy sufferers? Composition and quantitative aspects of the indoor pollen spectrum. Building Environ. 2017;123(10):78-87.

16 Menzel A, Matiu M, Michaelis R, Jochner S. Indoor birch pollen concentrations differ with ventilation scheme, room location, and meteorological factors. Indoor Air. 2016 27(3):539-50

17 Hugg T, Rantio-Lehtimäki A. Indoor and outdoor pollen concentrations in private and public spaces during the Betula pollen season. Aerobiologia. 2007;23(2):119-29.

18 Lee T, Grinshpun SA, Martuzevicius D, Adhikari A, Crawford CM, Luo J, et al. Relationship between indoor and outdoor bio-aerosols collected with a button inhalable aerosol sampler in urban homes. Indoor Air. 2006; 16(1):37-47.

19 Cariñanos P, Alcázar P, Galán C, Navarro R Domínguez E. Aerobiology as a tool to help in episodes of occupational allergy in work places. J Investig Allergol Clin Immunol. 2005; 14(4):300-8.
20 Mildenhall DC. An unusual appearance of a common pollen type indicates the scene of the crime. Forensic Sci Int. 2006;163(3):236-40.

21 Wu C-L, Yang C-H, Huang T-C, Chen S-H. Forensic pollen evidence from clothes by the tape Adhesive. Method. 2006;51(2):8.

22 Jantunen J, Saarinen K. Pollen transport by clothes. Aerobiologia. 2011;27(4):339-43.

23 Enevold R. Pollen studies of textile material from an Iron Age grave at Hammerum, Denmark. J Archaeological Sci. 2013;40(4):183844.

24 Schield C, Campelli C, Sycalik J, Randle C, Hughes-Stamm S, Gangitano D. Identification and persistence of Pinus pollen DNA on cotton fabrics: a forensic application. Sci Justice. 2016;56(1):29-34.

25 Webb JC, Brown HA, Toms H, Goodenough AE. Differential retention of pollen grains on clothing and the effectiveness of laboratory retrieval methods in forensic settings. Forensic Sci Int. 2018;288(7):36-45.

26 Boi M. Pollen attachment in common materials. Aerobiologia. 2015;31(2):261-70

27 D'Amato G, Cecchi L, Bonini S, Nunes C, Annesi-Maesano I, Behrendt $\mathrm{H}$, et al. Allergenic pollen and pollen allergy in Europe. Allergy. 2007;62(9):976-90.

28 Comert S, Karakaya G, Kalyoncu AF. Wraparound eyeglasses improve symptoms and quality of life in patients with seasonal allergic rhinoconjunctivitis. Int Forum Allergy Rhinol. 2016;6(7):722-30.

29 Ozturk AB, Celebioglu E, Karakaya G, Kalyoncu AF. Protective efficacy of sunglasses on the conjunctival symptoms of seasonal rhinitis. Int Forum Allergy Rhinol. 2013;3(12): 1001-6.

30 Kenney P, Hilberg O, Laursen AC, Peel RG, Sigsgaard T. Preventive effect of nasal filters on allergic rhinitis: a randomized, doubleblind, placebo-controlled crossover park study. J Allergy Clin Immunol. 2015;136(6): 1566-e5.

31 D’Amato G, Liccardi G, Salzillo A, Russo M, Narciso P, Allegra L. Nasal filters in prevention of seasonal rhinitis induced by allergenic pollen grains. Open Clinical Study. Eur Ann Allergy Clin Immunol. 2012;44(2):83-5. 
32 Gotoh M, Okubo K, Okuda M. Inhibitory effects of facemasks and eyeglasses on invasion of pollen particles in the nose and eye: a clinical study. Rhinology. 2005;43(4):266-70.

33 Morishima M, Kishida K, Uozumi T, Kamijo M. An investigation of the use of hay fever masks for the youth. J Hum Ergol. 2011;40(12):151-6.

34 Montali E, Mercuri AM, Trevisan Grandi G, Accorsi CA. Towards a "crime pollen calendar": pollen analysis on corpses throughout one year. Forensic Sci Int. 2006;163(3):21123.

35 Wiltshire PEJ. Hair as a source of forensic evidence in murder investigations. Forensic Sci Int. 2006;163(3):241-8.

36 Groenman-van Waateringe W. The Iceman's last days: the testimony of Ostrya carpinifolia. Antiquity. 2011;85(328):434-40.

37 Martin AJP. Tribo-electricity in wool and hair. Proc Phys Soc. 1941;53(2):186-9.

38 Penel V, Calleja M, Pichot C, Charpin D. Static and elevated pollen traps do not provide an accurate assessment of personal pollen exposure. Eur Ann Allergy Clin Immunol. 2017; 49(2):59-65.

39 Jones MD. Time of day of pollen shedding of some hay fever plants. J Allergy. 1952;23(3): 247-58.

40 Uguz U, Guvensen A, Tort NS. Annual and intradiurnal variation of dominant airborne pollen and the effects of meteorological factors in Çeşme (Izmir, Turkey). Environ Monit Assess. 2017;189(10):530.

41 Abreu I, Ribeiro H, Abreu I. Allergenic pollen in the city of Porto (Portugal). Allergy. 2008; 60(11):1452-3

42 Simoleit A, Gauger U, Mücke H-G, Werchan M, Obstová B, Zuberbier T, et al. Intradiurnal patterns of allergenic airborne pollen near a city motorway in Berlin, Germany. Aerobiologia. 2016;32(2):199-209.

43 Borycka K, Kasprzyk I. Hourly pattern of allergenic alder and birch pollen concentrations in the air: spatial differentiation and the effect of meteorological conditions. Atmos Environ. 2018;182(6):179-92.

44 Laaidi M. La périodicité intrajournalière des émissions polliniques. Utilisation dans la gestion quotidienne des pollinoses par les malades. Rev Francaise Allergol Immunol Clin. 2000;40(6):597-605.

45 Ishibashi Y, Ohno H, Oh-ishi S, Matsuoka T, Kizaki T, Yoshizumi K. Characterization of pollen dispersion in the neighborhood of Tokyo, Japan in the spring of 2005 and 2006. Int J Environ Res Public Health. 2008;5(1):76-85.

46 MacIntosh DL, Minegishi T, Kaufman M, Baker BJ, Allen JG, Levy JI, et al. The benefits of whole-house in-duct air cleaning in reducing exposures to fine particulate matter of outdoor origin: a modeling analysis. J Expo Sci Environ Epidemiol. 2010;20(2):213-24.

47 Jantunen J, Saarinen K. Intrusion of airborne pollen through open windows and doors. Aerobiologia. 2009;25(3):193-201.
48 Takahashi Y, Takano K, Suzuki M, Nagai S, Yokosuka M, Takeshita T, et al. Two routes for pollen entering indoors: ventilation and clothes. J Investig Allergol Clin Immunol. 2008;18(5):382-8.

49 Holmquist L, Vesterberg O; Arbetslivsinstitutet (Sweden). Airborne birch and grass pollen allergens in driving compartments of coaches. Stockholm: Arbetslivsinstitutet; 2001.

50 Hugg T, Valtonen A, Rantio-Lehtimäki A. Pollen concentrations inside private cars during the Poaceae and Artemisia spp. pollen season: a case study. Grana. 2007;46(2):110-7.

51 Muilenberg ML, Skellenger WS, Burge HA, Solomon WR. Particle penetration into the automotive interior. I. Influence of vehicle speed and ventilatory mode. J Allergy Clin Immunol. 1991;87(2):581-5.

52 Hashiguchi K, Tang H, Fujita T, Suematsu K, Tsubaki S, Nagakura H, et al. Pilot study of Japanese cedar pollen exposure using a novel artificial exposure chamber (Ohio Chamber). Clin Exp Allergy Rev. 2008;8(2):30-6.

53 Fahlbusch B, Hornung D, Heinrich J, Dahse HM, Jäger L. Quantification of group 5 grass pollen allergens in house dust. Clin Exp Allergy. 2000;30(11):1645-52.

54 Holmquist L, Vesterberg O. Quantification of birch and grass pollen allergens in indoor Air. Indoor Air. 1999;9(2):85-91.

55 Morgan RM, Allen E, King T, Bull PA. The spatial and temporal distribution of pollen in a room: forensic implications. Sci Justice. 2014;54(1):49-56.

56 Goodfellow HD. Industrial ventilation design guidebook. Elsevier; 2001. p. 1556

57 Sublett JL. Effectiveness of air filters and air cleaners in allergic respiratory diseases: a review of the recent literature. Curr Allergy Asthma Rep. 2011;11(5):395-402.

58 Fisk WJ. Health benefits of particle filtration. Indoor Air. 2007;23(5):357-68.

59 Krouse HJ. Environmental controls and avoidance measures. Int Forum Allergy Rhinol. 2014;4(Suppl 2);S32-4.

60 Gore R. Allergen avoidance: the attraction of charge. Clin Exp Allergy. 2002;32(4):483-5.

61 Reisman RE. Do air cleaners make a difference in treating allergic disease in homes? Ann Allergy Asthma Immunol. 2001;87(6 Suppl 3):41-3.

62 Bergmann KC, Sehlinger T, Gildemeister J, Zuberbier T. A novel experimental technology for testing efficacy of air purifiers on pollen reduction. Allergo J Int. 2017;26(1):1-6.

63 Orlandi F, Bonofiglio T, Sgromo C, Ruga L, Romano B, Fornaciari M. An applied aerobiological study to test the efficacy of pollen filters in limiting indoor pollen contamination. Grana. 2011;50(1):73-80.

64 Li Y, Xu Q, Zhang L, Wang X, Cao X, Yang X. Modern pollen assemblages of the forest communities and their relationships with vegetation and climate in northern China. J Geogr Sci. 2009;19(6):643-59.
65 De Linares C, Delgado R, Aira MJ, Alcázar P, Alonso-Pérez S, Boi M, et al. Changes in the Mediterranean pine forest: pollination patterns and annual trends of airborne pollen. Aerobiologia. 2017;33(3):375-91.

66 Honda K, Saito H, Fukui N, Ito E, Ishikawa K. The relationship between pollen count levels and prevalence of Japanese cedar pollinosis in Northeast Japan. Allergol Int. 2013;62(3): 375-80.

67 Grewling Ł, Šikoparija B, Skjøth CA, Radišić $\mathrm{P}$, Apatini D, Magyar D, et al. Variation in artemisia pollen seasons in central and eastern Europe. Agric For Meteorology. 2012; 160(7):48-59.

68 Kasprzyk I. Comparative study of seasonal and intradiurnal variation of airborne herbaceous pollen in urban and rural areas. Aerobiologia. 2006;22(3):185-95.

69 Kruczek A, Puc M. Phenology of flowering and pollen release of selected herbaceous plants in Szczecin and Gudowo (Western Pomerania) and the risk of pollen allergy. Acta Agrobot. 2012;65(4):49-60.

70 Bosch-Cano F, Bernard N, Sudre B, Gillet F, Thibaudon M, Richard H, et al. Human exposure to allergenic pollens: a comparison between urban and rural areas. Environ Res. 2011;111(5):619-25.

71 Skjøth CA, Smith M, Brandt J, Emberlin J. Are the birch trees in Southern England a source of Betula pollen for North London? Int J Biometeorol. 2009;53(1):75-86.

72 Šikoparija B, Skjøth CA, Alm Kübler K, Dahl A, Sommer J, Grewling 1, et al. A mechanism for long distance transport of Ambrosia pollen from the Pannonian Plain. Agric For Meteorol. 2013;180(10):112-7.

73 Izquierdo R, Belmonte J, Avila A, Alarcón M, Cuevas E, Alonso-Pérez S. Source areas and long-range transport of pollen from continental land to Tenerife (Canary Islands). Int J Biometeorol. 2011;55(1):67-85.

74 Groenman-van Waateringe W. Pollen in animal coats and bird feathers. Rev Palaeobot Palynol. 1998;103(1-2):11-6.

75 Craine JM, Barberán A, Lynch RC, Menninger HL, Dunn RR, Fierer N. Molecular analysis of environmental plant DNA in house dust across the United States. Aerobiologia. 2017;33(1):71-86.

76 Riding JB, Rawlins BG, Coley KH. Changes in soil pollen assemblages on footwear worn at different sites. Palynology. 2007;31(1):13551.

77 Ariano R, Mistrello G, Mincigrucci G, Bricchi E, Lannotti $O$, Frenguelli $G$, et al. In vitro and in vivo biological activities of old and fresh Cupressus arizonica pollen. J Investig Allergol Clin Immunol. 2006;16(3):177-82.

78 Shahali Y, Brazdova A, Calleja M, Charpin D, Sénéchal H, Poncet P. Indoor, long-term persistence of cypress pollen allergenic potency: a 10-month study. Ann Allergy Asthma Immunol. 2013;111(5):428-30.
Evaluation of the Recommendations for Patients with Pollen Allergies
Int Arch Allergy Immunol 2020;181:839-852 DOI: $10.1159 / 000510313$ 
79 Urgacz A, Mrukwa E, Gawlik R. Adverse events in allergy sufferers wearing contact lenses. Postepy Dermatol Alergol. 2015;32(3): 204-9.

80 Markoulli M, Papas E, Cole N, Holden B. Corneal erosions in contact lens wear. Cont Lens Anterior Eye. 2012;35(1):2-8.

81 van Doorn K, Subbaraman L, Lemp J, Maissa C, Jones L. Design and validation of a device for modeling pollen adhesion to contact lenses. Contact Lens and Anterior Eye. 2018;41: S5.

82 Kari O, Haahtela T. Is atopy a risk factor for the use of contact lenses? Allergy. 1992;47(4 Pt 1):295-8.

83 Bailey CS. Allergic conjunctivitis and contact lens wear. J Br Contact Lens Assoc. 1991; 14(4):219-21.

84 Hayes VY, Schnider CM, Veys J. An evaluation of 1-day disposable contact lens wear in a population of allergy sufferers. Cont Lens Anterior Eye. 2003;26(2):85-93.

85 Wolffsohn JS, Emberlin JC. Role of contact lenses in relieving ocular allergy. Cont Lens Anterior Eye. 2011;34(4):169-72.

86 Solomon WR. Aerobiology of pollinosis. J Allergy Clin Immunol. 1984;74(4 Pt 1):449-61.
87 Enomoto T, Onishi S, Sogo H, Dake Y, Ikeda $\mathrm{H}$, Funakoshi $\mathrm{H}$, et al. Japanese cedar pollen in floating indoor house dust after a pollinating season. Allergol Int. 2004;53(3):279-85.

88 Bruffaerts N, De Smedt T, Delcloo A, Simons K, Hoebeke L, Verstraeten C, et al. Comparative long-term trend analysis of daily weather conditions with daily pollen concentrations in Brussels, Belgium. Int J Biometeorol. 2018; 62(3):483-91.

89 Rodríguez de la Cruz D, Sánchez-Reyes E, Sánchez-Sánchez J. A contribution to the knowledge of Cupressaceae airborne pollen in the middle west of Spain. Aerobiologia. 2015;31(4):435-44.

90 Méndez J, Comtois P, Iglesias I. Betula pollen: one of the most important aeroallergens in Ourense, Spain. Aerobiological studies from 1993 to 2000. Aerobiologia. 2005;21(2):11524.

91 Sabit M, Ramos JD, Alejandro GJ, Galan C. Seasonal distribution of airborne pollen in Manila, Philippines, and the effect of meteorological factors to its daily concentrations. Aerobiologia. 2016;32(3):375-83.

92 Marceau A, Loubet B, Andrieu B, Durand B, Foueillassar X, Huber L. Modelling diurnal and seasonal patterns of maize pollen emission in relation to meteorological factors. $\mathrm{Ag}$ ric For Meteorology. 2011;151(1):11-21.
93 Fernández-Rodríguez S, Tormo-Molina $\mathrm{R}$, Maya-Manzano JM, Silva-Palacios I, Gonzalo-Garijo Á. A comparative study on the effects of altitude on daily and hourly airborne pollen counts. Aerobiologia. 2014;30(3):25768.

94 Hernández-Ceballos MA, García-Mozo H, Galán C. Cluster analysis of intradiurnal holm oak pollen cycles at peri-urban and rural sampling sites in southwestern Spain. Int J Biometeorol. 2015;59(8):971-82.

95 Nayar TS, Jothish PS. An assessment of the air quality in indoor and outdoor air with reference to fungal spores and pollen grains in four working environments in Kerala, India. Aerobiologia. 2013;29(1):131-52

96 Holmquist L, Weiner J, Vesterberg O. Airborne birch and grass pollen allergens in street-level shops. Indoor Air. 2001;11(4): 241-5.

97 Ugolotti M, Pasquarella C, Vitali P, Smith M, Albertini R. Characteristics and trends of selected pollen seasons recorded in Parma (Northern Italy) from 1994 to 2011 . Aerobiologia. 2015;31(3):341-52.

98 Pérez CF, Gassmann MI, Covi M. An evaluation of the airborne pollen-precipitation relationship with the superposed epoch method. Aerobiologia. 2009;25(4):313-20 